\title{
A partner selection framework for strategic alliances based on project complexity and partner's past experience
}

\author{
Maliheh Vaez-Alaei $\mathbb{D}^{\mathrm{a}, \mathrm{b}}$, loana Deniaud (D) ${ }^{\mathrm{a}}$, François Marmier (D) ${ }^{\mathrm{a}, \mathrm{c}}$, Didier Gourc (iD ${ }^{\mathrm{b}}$ \\ and Robin Cowan ${ }^{\mathrm{a}, \mathrm{d}}$ \\ aUniversity of Strasbourg, University of Lorraine, CNRS, BETA, Strasbourg, France; bIndustrial Engineering \\ Center, Toulouse University, IMT Mines Albi, Albi, France; 'ICUBE, CNRS UMR 7357, Strasbourg University, \\ Strasbourg, France; dUNU-MERIT, Maastricht University, Maastricht, The Netherlands
}

\begin{abstract}
In a complex innovative project, an organisation is often not able to manage all aspects alone, due to the lack of all required competencies, skills or resources. Hence, alliance formation can be a solution. To decrease the risk of potential collaboration inefficiency, partner selection happens among firms before collaboration starts. This paper proposes hypotheses based on a systematic literature review. These hypotheses consider the needs of the project and allow to characterise partner selection using a new typology. Finally, a novel framework is proposed to help decision-makers of partner selection in alliance formation. Potentials for future studies are also developed.
\end{abstract}

\author{
KEYWORDS \\ Strategic alliances; trust; \\ knowledge; project \\ complexity; risk \\ management; partner \\ selection
}

\section{Introduction}

Today, faced with the global reorganisation of production structures and increased competition due to the ongoing reduction of trade barriers, it is even harder for firms to compete. A standard solution to that problem is innovation. But as technology changes, products and processes become more complex, involving more and different types of knowledge. Very often firms are faced with a situation where the knowledge, competence or technology they need to make the next competitive step is not available in-house. In response, firms collaborate with other firms: since the late 1970s we have seen an impressive increase in firms making 'strategic alliances'. An alliance permits partnering firms to share knowledge, technology, and possibly other resources, without losing independence (Chung, Singh, and Lee (2000); Furlotti and Soda (2018); Chen and Goh (2019)), and successful partnerships combine diverse skills and resources to achieve a predetermined set of objectives. While there has been considerable literature extolling the virtues of strategic alliances, it must be observed that the majority of alliances (some measure up to 60\%) are considered failures by the partnering firms (Bruner and Spekman (1998)). While acknowledging that failure is an inseparable part of innovation, and sharing knowledge and technology between partners is not immune to risk (Rosas et al. (2017)), to 
a great extent poor performance of an alliance can be ascribed to a lack of 'fit' between or among partners. In particular, a lack of trust, but also miscommunication, cultural discrepancies, or hidden objectives all arise to inhibit cooperation (Wong, Shek-, and Cheung (2004), Kramer and Tyler (1995)). Thus, while technological complementarity is a necessary condition for a successful alliance, another important factor in the search for a good partner, in particular when thinking about the risks inherent in any cooperation is whether the partners can work together.

Given that entering an alliance implies giving up a certain amount of control, it seems clear that trust would be a dominant factor in alliance success. Working in an alliance creates dependency among the partners: each has invested in the partnership, but by the very nature (and raison d'etre) of an alliance, the success of any partner depends on the actions of the others. Consequently, the initial and ongoing investments (financial, technological, knowledge ...) are predicated on the assumption that other partners will not cheat. Partnership relationships then tend to be deeper than pure market-based relationships and this is necessary to induce effective knowledge sharing (Xu and Qingguo (2008)), and when trust is evident, the quality of communication and dialogue are greatly improved (Sarker et al. (2005). Creation and maintenance of trust are facilitated by common mutual expectations with regard to the content of the project, but Park and Lee (2014) also observe that the creation of trust is easier when partners have a similar view on the value of the partnership and how knowledge should be shared.

The latter issue is now widely discussed in the literature; Lai and Reiter (2000), for example, argue that collaborators with more similarity along different dimensions culture, learning ability, geographic distance and threat - are more likely to cooperate with each other. But, recalling that firms engage in alliances to access resources (broadly defined) that they do not have in-house, partnerships are more likely to exist between firms that have complementary resources, skills or technologies (Chung, Singh, and Lee (2000); Ahuja and Katila (2001); Mowery, Oxley, and Silverman (1996, 1998); Stuart (1998)). But other dimensions also matter: Rosenkopf and Almeida (2003) explored the relationship between partner similarity (in terms both of geography and technology) and alliance success or firms' willingness to participate. Both axes are critical in understanding partner selection and alliance formation. The complementarity and similarity of these characteristics should be considered when trying to understand partner selection and alliance success (Capaldo and Petruzzelli (2014)). Success also depends on the partnership being structured such that there is a fit among tasks, actors and resources. A better match between task assignment and actors' resources increases the probability of allying (Furlotti and Soda (2018)).

Several papers have looked at various aspects of alliance formation. For example, Gulati, Wohlgezogen, and Zhelyazkov (2012) observe the importance of past collaboration experiences, resource compatibility, and partners' status. Kim and Parkhe (2009) model alliance formation based on cooperating and competing similarities (which also appear in (Gulati, Wohlgezogen, and Zhelyazkov (2012)) finding empirically that the former has a positive, and the latter a negative impact on alliance outcomes. Mudambi and Tallman (2010) argue that basing alliance partner selection on knowledge similarity and close geographic distance has positive effects on innovation performance. Deniaud et al. (2017) argue that evaluating projects to rank them as technologically simple or challenging plays an effective role in the partner selection phase. 
The literature identifies several different axes which are relevant for alliance success and thus (implicitly or explicitly) finding and selecting partners. The two broad axes are knowledge and trust but within each of these, there are a variety of more fine-grained considerations. That said, an over-arching framework that covers these considerations in partner selection is missing from the general literature. Given the continued increase in alliances as part of the strategy space of many firms, such a framework could serve as the basis for a decision-making tool that would assist firms in finding partners that fit best with themselves and with the project they want to undertake.

In this paper, which is an extended version of an IESM 2019 conference paper (VaezAlaei et al. (2019)), the contribution is to propose a partner selection framework, based on a new typology, that aims to maximise the success probability of an alliance. The first novelty of the proposed framework is to consider both partner's history and project technological complexity to find a basis to evaluate the set of partnerships based on their knowledge and competencies. The second novelty is to introduce a new aspect of knowledge classification named coverage, in addition to similarity and complementarity. We also define different levels of trust in the proposed framework as a variable to consider in choosing the best set of partners. The remaining sections of this paper are organised as follows: Section 2 presents a comprehensive literature review of previous research on partner selection; in Section 3, proposed theory and hypotheses regarding partner selection in alliances are provided; the proposed framework approach is explained in Section 4; the paper ends with conclusion and discussions in Section 5.

\section{Literature review}

Partnership and collaboration between independent organisations are fundamental issues in many fields, including social sciences, communications, computer science, physics, and even biology and ecosystem (Dorogovtsev and Mendes (2013)). A large variety of partnership's form has emerged depending on the nature of the relationship between partners as well as their collaboration strategy, for instance, Collaborative Network (CN), Virtual Organisation (VO), Virtual Breeding Environment (VBE), Supply Chain Network (SCN), strategic alliance, partnership, collaborative project, and so on.

It is no surprise then that research on collaborations has been very broad-based in different scientific disciplines. The web of science counts around 9000 papers that contain the expression 'Strategic Alliances', 'Collaborative Networks' and 'Virtual Organisations' in the title, abstract or keywords provided by authors over the period 1995 to 2019 (www. webofknowledge.com). Figure 1 shows the publication trend for each keyword per year and also the increasing trend in the total number of papers which were published each year.

A state-of-the-art analysis of collaborative networks for service-based innovation ecosystems has been developed by WP2.5 of the MSEE project (Manufacturing SErvices Ecosystem) (Loichate (2012)). More than producing a synthetic definition of collaborative network, this study focuses on the collection, comparison and evaluation of all types of collaborative networks and their applicability in manufacturing ecosystems.

Salah et al. (2018) presented a synthetic description collaboration forms following several other works especially those of (Ferrada and Camarinha-Matos (2019); Camarinha- 


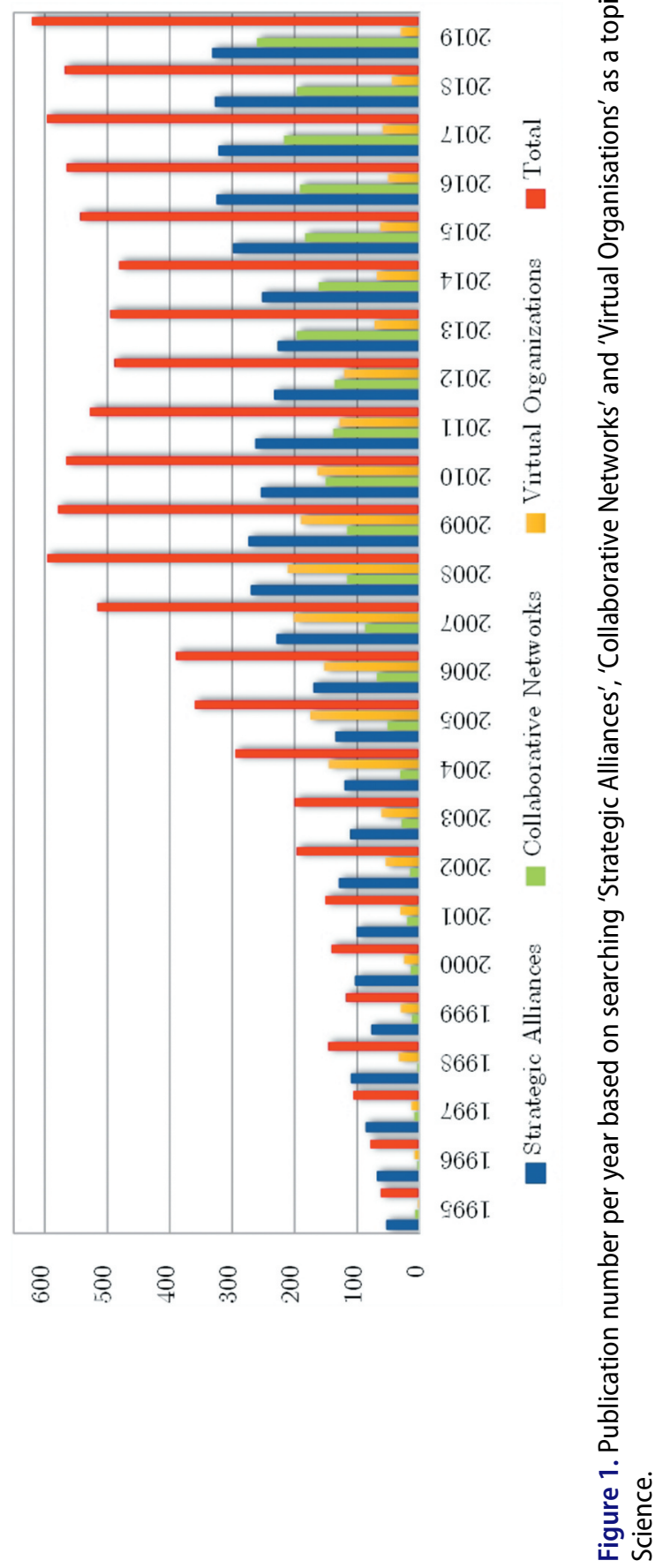


Matos et al. (2009b); Camarinha-Matos and Afsarmanesh (2005); Camarinha-Matos et al. (2009a)) who have largely studied the concept of virtual enterprise and collaborative networks since 1998. Based on these works, most researchers have studied the need for developing collaborative networks according to IT perspectives and the effects on the performance of firms in various industry sectors, such as the chemical industry and manufacturing industry.

Other researchers have conducted works on the same field but from different aspects and perspectives such as alliance or network in construction companies (Haghbin and Davoudi (2014)), collaborative project management (Shevtshenko et al. (2015)), sustainable collaborative networks (Camarinha-Matos and Boucher (2012); Camarinha-Matos, Afsarmanesh, and Boucher (2010)), green virtual breeding environment (Romero and Molina (2011)), product-service system engineering (Elhabib, Boucher, and Peillon (2010)), and manufacturing industries (Kohl et al. (2015)).

For example, the expression 'strategic alliance' refers to a variety of (usually formalised) inter-firm partnerships (Osborn and Hagedoorn (1997)) in which partner firms share resources to achieve predetermined objectives, while maintaining independence. Compared to integration through acquisitions and mergers, firms engaged in strategic alliances receive several advantages: expanding customer base; networking opportunities; higher levels of innovation; increasing the chance of survival, learning and training, higher returns on equity/investment among others (Todeva, Knoke (2005); Haghbin and Davoudi (2014)). It is confirmed that owing to the cross-disciplinary essence of collaboration, there is no consensus on the use of terms such as 'partnership', 'alliance' and 'network' (Durugbo (2016)).

A partnership has a life cycle which is divided into major phases. Camarinha-Matos and Afsarmanesh et al. (2012) indicate that the evolution of a CN may be divided into three major phases: creation phase, phase of daily business and a phase of changing nature (Camarinha-Matos et al. (2019); Camarinha-Matos and Afsarmanesh (2018)).

The creation phase also named formation phase is divided into four steps according to (Harbison and Pekar (1997)) and each of these steps or a combination of some of them has been studied in numerous research in the literature. The first step is the identification of the potential partners based on the objective of the collaboration (Wong, Leung-, and Ellis (2002). The second step is evaluation of potential partners to select the best fit based on different criteria (Polyantchikov et al. (2017); Furlotti and Soda (2018)); negotiation with the selected partners to determine terms of collaboration and to finalise the partner selection (Oliveiral, Camarinha-Matos, and Michel (2008); Camarinha-Matos et al. (2009b); Afsarmanesh, Camarinha-Matos, and Simon Samwel (2010); and implementing the strategic alliance (Osório et al. (2019); Gou et al. (2019)). In this study, we focus on the evaluation step and partner selection based on some of the influential criteria. In the following subsections, first partner selection problem is discussed and then we focus on its influential criteria.

\subsection{Partner selection problem and most commonly used criteria}

Partner Selection (PS) is a crucial step of the strategic alliance formation Crispim, Rego, and de Sousa (2015); Durugbo (2016)). It consists of evaluating and selecting the partners, 
who have the required skills to maximise the success rate of the collaboration or the project.

Salah et al. (2018) divided the PS process into four activities: criteria formulation, partners qualification, final selection of qualified partners and application feedback in which the decision-makers (DMs) evaluate the members to improve the effectiveness of the network by ensuring that the most suitable partners are selected at all times.

Several papers addressing this problem are proposed in the literature. They are based on mathematical models and methodologies with qualitative or quantitative factors, such as 'Analytic Hierarchy Process (AHP), Analytic Network Process (ANP), Case-Based Reasoning (CBR), Data Envelopment Analysis (DEA), fuzzy set theory, Genetic Algorithm (GA), mathematical programming, Simple Multi-Attribute Rating Technique (SMART), Lagrangian relaxation and their hybrids' Ho, Xiaowei, and Dey (2010); Maleki, Shevtshenko, and Cruz-Machado. (2013)), etc.

Determining the right set of criteria for partner selection is not an easy task. The authors propose a list of most used partner-related criteria according to their studies (Mat et al. (2009)). Polyantchikov et al. (2017) focused on sustainable partner networks in which based on the interviews of managers of companies ranked the partner selection criteria. Their result showed that it is critical to consider quality, delivery and cost in partner selection. Based on an online survey that targeted organisations from Malaysia, Australia and other countries (such as India, Singapore and the Philippines), the authors propose a ranked list of criteria for selecting partners. Some of the most used PS criteria are similarity in objectives, project management experience, ability to negotiate, previous successful collaboration and cultural similarity. According to Mat et al. (2009), in strategic alliances, for example, intangible factors of potential partners have a significant impact on the long-term viability of the alliance". Examples of such factors are culture, trust, managerial know-how, reputation or other soft aspects that could aid in partner selection.

Current globalisation and competitive pressures are pushing firms to bring forward innovation in products, processes and services. It is becoming more and more critical to innovate due to the evolution of customer demand towards more and more sophisticated products and services. The whole idea behind the strategic alliance is that sharing knowledge among firms during collaboration facilitates innovation. Nevertheless, firms' collaborations are often very complex, and it is well known that many alliances do not achieve their predefined objectives (Bruner and Spekman (1998); Gulati, Wohlgezogen, and Zhelyazkov (2012)).

Interactions and exchanges between partners is a key factor in sharing knowledge and driving innovation, especially in complex projects with various partners involved. Sharing knowledge can be increased through incentives and IT support, but possibly more importantly, through organisational culture and trust (Lyu and Zhang (2017); Moorman, Deshpande, and Zaltman (1993)). It is also the case that there is a potential virtuous cycle: authors point out the positive effect of information sharing on trust between partners (Aulakh, Kotabe, and Sahay (1996)), which illustrates a two-way (causal) relationship between mutual trust between partners and their willingness to share information.

According to the literature, trust is a psychological condition of individual partners in the project partnership (Kadefors (2004)). To trust someone (or something) is often characterised as a willingness to take certain types of risks, thereby making oneself vulnerable (Becker (1996)). In principle, trust is a way of mitigating the risks involved in 
any investment or any joint venture. An increase in trust increases the willingness to make investments where part of the risk lies in the partner's future behaviour. One can expect then that the more trust involved, the more enthusiasm in participating in the project, and so the more likely is project success (Cook, Hardin, and Levi (2005)).

Several authors have drawn attention to the role of the level of trust on the commitment to collaborate. Kamel et al. (2007) presented the need to build a group of agents who trust each other which allows them to open their information systems while maintaining control of their critical resources. Belkadi et al. (2017) proposed a framework to define a trust level to choose collaboration strategy in alliances, and described different collaboration modes based on different levels of trust. Similarly, Ferrada and CamarinhaMatos (2019) studied different collaborative networks and proposed a novel approach based on players' emotional criteria closely related to trust. They argued that this approach could help in establishing mutual trust between partners.

\subsection{Influential factors in strategic alliances}

Based on the importance of partner selection and the gap we have observed in the literature, the paper focuses on alliance formation and investigates the central role played by trust in partner selection. The literature on partner selection has identified a large variety of critical criteria and frameworks. In the following subsections we present a review of different factors affecting trust, knowledge sharing between partners and project success in alliance formation.

\subsubsection{Partners' past experiences}

'The more alliances you do, The better you get at them' (Harbison (1998)). This sentence encapsulates the results of many studies in this field.

Partnership leads to learning and learning leads to growing knowledge, and increasing knowledge is a way to decrease the chance of failure in alliances (Braunerhjelm (2010)). But it is important to note that increasing knowledge is not enough to be successful, the important point is to be motivated to convert existing or new knowledge into something that can be communicated or can be used for managerial or technological aspects of a partnership. This conversion is non-trivial and is typically an activity that involves both partners, which implies, again, that past experience working in alliances can be beneficial, provided current partners are motivated to work together. Sampson (2002) used a sample data of R\&D alliances of organisations in the telecom equipment industry to discuss the ability of firms to learn to collaborate, and its effect on future partnerships. The results showed that although all organisations learn from cooperation and increase their knowledge, not all the knowledge gained is productive for future alliances. Acquired knowledge mostly has a positive effect on future allies, but only for a short time after the alliance at issue, due to knowledge obsolescence.

Guardo and Harrigan asked whether a firm's past alliance experiences have a positive influence on the degree of innovativeness in future alliances (Di Guardo and Harrigan (2016)). They found that past learning is more effective when a firm displays a wide diversity of R\&D alliances. Emden, Yaprak, and Tamer Cavusgil (2005) concluded that learning orientation and organisational commitment to the partnership are two criteria that affect firms' abilities to learn during an alliance. Thus, these factors can be considered 
central in determining the success of an alliance, and shape the way learning from past alliances feeds into future success.

The important role of trust and its relation to the past and present has been studied. A history of collaboration represents a sort of knowledge to each partner representing the history of performance and cooperation in a collaborative network which also shows the trust level (Afsarmanesh, Camarinha-Matos, and Msanjila (2009); Msanjila and Afsarmanesh (2011)). Tenera and Rosas (2019) presented a novel perspective of constraints in the management of collaborative networks in which partners have been evaluated in terms of, past collaboration, trustworthiness and reliability. Typically, any collaboration starts with a low level of trust and integration between partners. If all goes well, as the result of successful interaction trust levels increase. As a consequence of the growth in trust, the partnership can move to a more complex project and coordination (Belkadi et al. (2017)). This will carry over from one project to the next, so that partners that have already successfully collaborated with each other have more willingness to trust each other. Meier et al. (2016) proposed a hypothesis about the positive effect of cooperative history on mutual trust in strategic alliances. Using a database of social science research network, they showed that a cooperative history has a significant positive effect on mutual trust in alliances.

There is a consensus in the literature that there is a significant relationship between firms' past experiences and their future performance in collaborations. It is clear that this relationship is not direct, and it can be affected by many different factors. Some of these factors, such as complexity and knowledge, are considered in this paper and discussed in the following subsection.

\subsection{Project complexity}

The nature and degree of its complexity are central to determining the appropriate style for managing a project, and this has been widely discussed in the literature. Project complexity has effects on the selection due to the effect of organisational complexity in project management, since managing projects goals (such as time and cost) with higher organisational complexity is more complicated (Baccarini (1996)). Every project is complex to a greater or lesser extent, and the inability to deal with it is often cited as a reason for project failure (Bakhshi, Ireland, and Gorod (2016)). One element that makes a project complex is unexpected events that arise either due to the actor's behaviour or to project characteristics, and the potential for these surprises creates difficulties in estimating completion time, cost and quality (Vidal and Marle (2008)), and consequently contributes to a project failing to achieve its expected objectives. Relich and Pawlewski (2018) studied the relationships between past New Project Development (NPD) time and cost estimation, and developing new products. Previous data in organisational databases were considered as potential sources of information, and a neural network model was used to estimate the cost of a new product based on the past data Nguyen et al. (2019). Bernus et al. (2016) identified four different challenges in information systems: scope, scale and complexity, sustainability and viability, and finding survival modes. In terms of resource allocation and project scheduling, they concluded that project complexity has a direct relation with risks of failure. 
The most commonly observed forms of complexity in the project management literature are organisational complexity and technological complexity (Baccarini (1996); Mintzberg (1989)). The former includes relationships with respect to reporting, communication between partners, task allocation, etc. The latter can be defined as the degree of challenge in processing inputs to outputs as this process can include complicated combinations of skills, material, knowledge and techniques.

Project complexity has been seen as a moderator in models of alliance governance, and theoretically has been implemented in different ways. Benítez- Ávila et al. (2018) include in their model that relational norms, partners' trust and partners' contribution are affected by this complexity. Causality, complexity, transparency, and fairness have been identified as the main challenges of trust in virtual organisation breeding environments (Msanjila and Afsarmanesh (2008); Msanjila and Afsarrnanesh (2006)). Alsaad, Mohamad, and Ismail (2017) used complexity as an independent variable affecting perceived desirability. For Sunardi, Tjakraatmadja, and Bangun (2015), cultural discrepancies increase a project's organisational complexity, which negatively affects knowledge sharing between partners. Finally, complexity creates a space in which innovation is comparatively hard to understand, achieve and use. It is related to the idea that complexity is a deterrent to innovation adoption because it raises uncertainly and the risk of failure (Hameed and Counsell (2014)). The less complex is a project, the easier it is to evaluate, and so the faster the growth in trust which facilitates innovation (Robson, Katsikeas, and Bello (2008)).

\subsection{Knowledge criteria}

Creating new knowledge is an important activity for all firms, especially those in industries in which technologies are changing. But even in old and technologically stable industries, new knowledge can still be a source of competitive advantage (Inkpen (1998)). Naturally, as innovation is nothing more than the creation of new knowledge, typically out of existing knowledge, appropriate knowledge management has a great positive effect on innovative activities (Li, Zhang, and Zheng (2019)). Any competence of a firm can be characterised as some kind of knowledge, and one of the important goals of an alliance is to share knowledge among partners. Accordingly, when partners are being selected, it is necessary to evaluate their knowledge (broadly defined) to look for cases of good knowledge fit and complementarity. In the current study, firms' knowledge positions can be characterised along three dimensions: similarity, complementarity and coverage (VaezAlaei et al. (2019)), which are explained below and shown in Figure 2.

\subsubsection{Similarity and complementarity}

The need for similarity and complementarity in knowledge, and their role in partnerships are not new subjects, and both have been broadly discussed in recent years. In this section, we recall some of this discussion to lay the groundwork for our development of the general framework, and the introduction of a third knowledge concern appropriate to partner selection.

Effective communication is a basic foundation for successful cooperation between partners. This is particularly the case as projects become more complex. When firms hold similar knowledge stocks (in terms of the type of knowledge) communication is simplified 


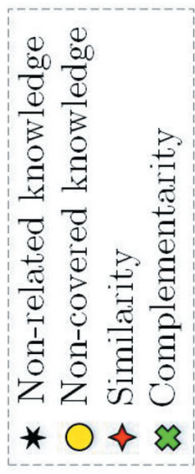

峁
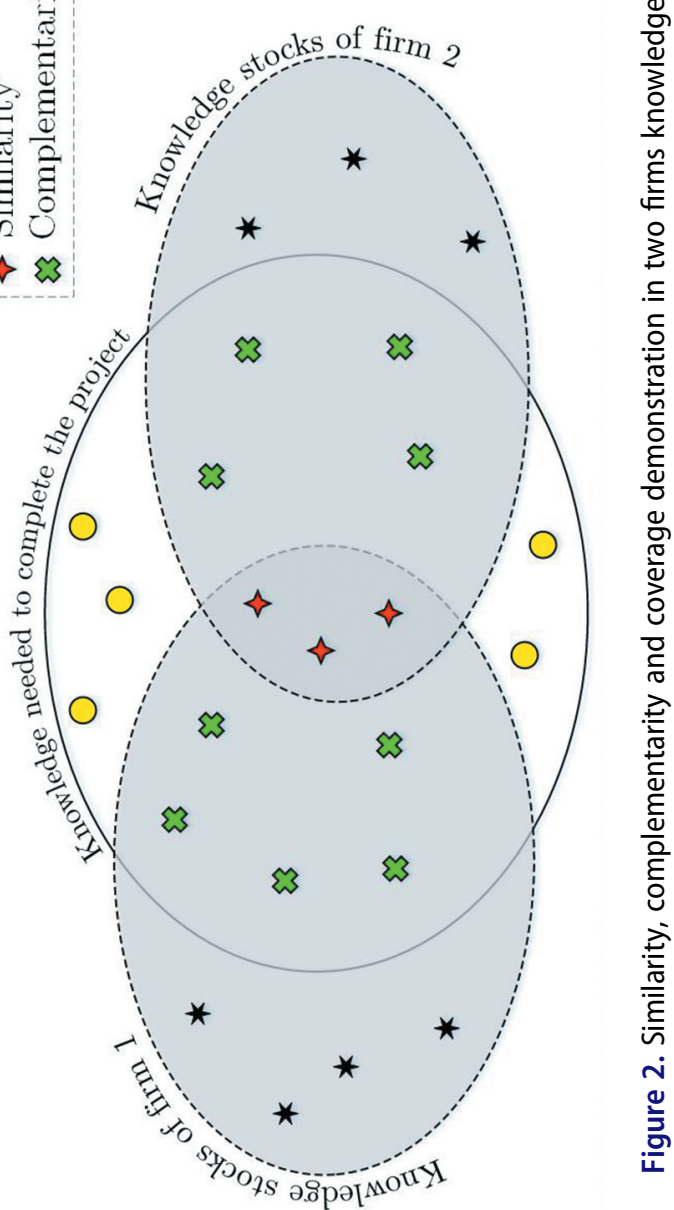
as each can easily understand the other; miscommunication is minimised and the risk of failure for that reason is reduced.

Rosenkopf and Almeida (2003) discussed knowledge localisation in both geographical and technological aspects. They suggested that similarity in knowledge can defeat the communication constraint in alliances. Further, though, cognitive similarity facilitates interaction, and thereby helps to build trust between partners (Capaldo and Petruzzelli (2014)). Kim and Parkhe (2009) differentiate between competing similarity and cooperating similarity. By using data from US firms' cross-border alliances, they found negative effects of competing similarity and positive effects of cooperating similarity on alliance success. Similarity in foreign policies of firms and geographic configuration localisation can also be a motivation for partners to form alliances (Fordham and Poast (2016)). Camarinha-Matos et al. (2009b) studied the partner selection and negotiation in VBE considering identification of weakness in collaborations, such as lack of reliable information of potential partners and maladjustment due to the different infrastructure. So they considered collaboration history, trust and similarity of infrastructures in partner selection phase. In addition to cognitive similarity, many scholars have observed that similarity along other dimensions can be valuable: as variables that affect trust between partners, or that ease interpersonal communications (Ahlf et al. (2019); Doloi (2009)), similarity in shared values Wu, YingHueih, and Yu-Shuo (2010) and similarity in shared goals (Chen, Lin, and Yen (2014)) have been noted.

Alliances will be created when there is an idea that firms in combination will have a greater effect than they will separate. Knowledge complementarity exists when the knowledge stocks of the partners are different from each other, but in addition, the stocks are different in ways that mean that when they combine, they are greater than the sum of the parts. There are several papers that have identified the important role of complementarity in partnerships.

Cobeña, Gallego, and Casanueva (2017), for example, analysed the role of diversity in resources by considering data on airline alliances: Computational results showed that having recourse to complementarity causes a better operational level performance. Furlotti and Soda (2018) studied complementarity and similarity in alliance formation generally. Their results showed that there is a direct relation between the probability of firms allying, and adjustment among tasks and resources. They also noted that not just knowledge stocks but also tasks should be considered in evaluating resource complementarity. Mostly it is indicated in the literature that sharing knowledge and learning between partners has a direct influence on enhancing new product performance (Deniaud et al. (2017); Relich and Pawlewski (2018)). Uwizeyemungu et al. (2018) studied the importance of complementarities between information technology and noninformation technology capabilities. They checked the effect of different combinations of these resources on competitive performance in small and medium-sized enterprises. A previous study, which used data from international mutual investment in China, suggested that knowledge absorption of partners plays a critical role in learning and innovation (Yao et al. (2013)).

It can be concluded from previous research that cooperating similarity between partners causes a higher level of alliance capability and more effective relationships (Bruner and Spekman (1998); Kim and Parkhe (2009)). Also resource complementarity 
was identified as a very influential factor in enhancing stability and trust in ongoing collaboration (Deitz et al. (2010)). Huang, Hsiung, and Ting-Chun (2015) studied joint venture performance. Value gap and information asymmetry mediate the relationship between control variables and performance. So the importance of knowledge complementarity is related to both project and partner characteristics.

The discussion of similarity and complementarity in knowledge stocks suggests that there would be an inverted-U relationship between distance and knowledge space, and either the success of an alliance or the likelihood that two firms would ally. Indeed, this has been observed empirically (Mowery, Oxley, and Silverman $(1996,1998)$ ). But is this enough? We propose below that there is a third aspect of knowledge stocks relevant to alliance formation and success, namely coverage. Further, though, where the peak of the inverted- $U$ is located may be dependent on other characteristics of the firms, the partnership and the project. These are the issues we take up in the following sections.

\subsubsection{Coverage}

The needs of the project are a reason for different partners to ally - to use others' knowledge, or to learn from knowledge sharing. So, learning is assumed as one of the most important reasons for allying (Muthusamy and White (2005)). There are two factors which are important in selecting partners, first the desire of partners to work with each other, and second is the availability of the resources relevant to the project, which we refer to as 'coverage'. The latter idea is not much discussed in the literature, but does seem central to the entire operation of an alliance. One way to operationalise coverage is as the ratio of total knowledge available in the partnership to the knowledge required to perform the project successfully. Coverage contains both similarity and complementarity in knowledge and is defined by Equation 1.

$$
\text { Coverage }=\frac{\text { Similarity }+ \text { complementarity }}{\text { Similarity }+ \text { complementarity }+ \text { Non covered knowledge }}
$$

The difference between similarity, complementarity and coverage is shown in Figure 2, which serves as a schema for understanding how potential partners can position each other and the project's needs using these criteria, at the beginning of the project.

In Figure 2, as an example, there are two firms with their own knowledge stocks, which are collaborating on a project. The two grey ellipses represent the knowledge stocks of the two firms; the transparent ellipse represents the knowledge needed to complete the project. These knowledge stocks can be any competencies, expertise, technology or resources in a firm. Not all the knowledge in a firm is related to collaboration. Among related knowledge, there is some which are known by both firms, generating similarity; there is some knowledge related to the project that is known by only one or other of the firms, and this creates complementarity; the proportion of all the knowledge, similar or complementary to the knowledge that these firms need to finish the project, generates coverage. The two firms may jointly cover all the knowledge needed for the project, or they may not, in which case they will either have to generate it, or find it elsewhere.

As a conclusion to the literature review, although the research in this field is so rich, a partner selection framework which has a closer look at the link between partner's history of collaboration and projects degree of complexity is missing. Considering all the 
mentioned scholars, two gaps in the existing literature can be identified on alliance partner selection. The first gap concerns different knowledge criteria (similarity, complementarity and coverage) and their relationships with partners and project characteristics. Second, differences in trust level considering the degree of project complexity and history of collaboration have not yet received much attention. Table 1 shows the criteria considered in some of the reviewed research and current paper.

\section{Proposed hypotheses}

This research is conducted based on previous studies to establish a framework for a better understanding of the collaboration aspects in alliances. In this paper, considering the classification in the literature review section, two important factors are used to define a framework for partner selection. First is whether the project is technologically simple or challenging (complex). The knowledge complexity of a project arises not only in the technology itself but also in how the technology fits into the knowledge competence of each other the partners and how those competences interact. Second, is whether partners know each other or if it is their first collaboration, which leads directly to the issue of trust. Besides partner selection, this evaluation would help participants to estimate project objectives like time and cost. Figure 3 shows the schematic view of alliance formation steps by (Harbison and Pekar (1997)) and our proposed framework which is the development of its second step.

Based on the literature review indicated in Section 2, summarised in Table 1, and our contributions about selecting partners in network of alliances, four hypotheses are proposed to design a framework in this paper.

Hypothesis 1: If the project is technologically simple and partners knew each other (or their past projects were successful), then the mutual trust level is high; budget and time can be estimated with confidence and complementarity is more important.

Hypothesis 2: If the project is technologically simple but it is the first collaboration of partners (or past projects had difficulties), then the mutual trust would have an intermediate level (since technological simplicity would argue for high trust but partner nonfamiliarity would argue for low trust); budget and time can be estimated with confidence, and relative to coverage, similarity and complementarity have more weight in partner selection.

Hypothesis 3: If the project is technologically challenging and partners knew each other (or their past projects were successful), then we expect intermediate levels of mutual trust; budget and time cannot be estimated with confidence, and complementarity and coverage are more important.

Hypothesis 4: If the project is technologically challenging and it is the first collaboration between partners (or past projects had difficulties), then the mutual trust level is low; budget and time cannot be estimated with confidence, and similarity, complementarity and coverage are all important in partner selection. 


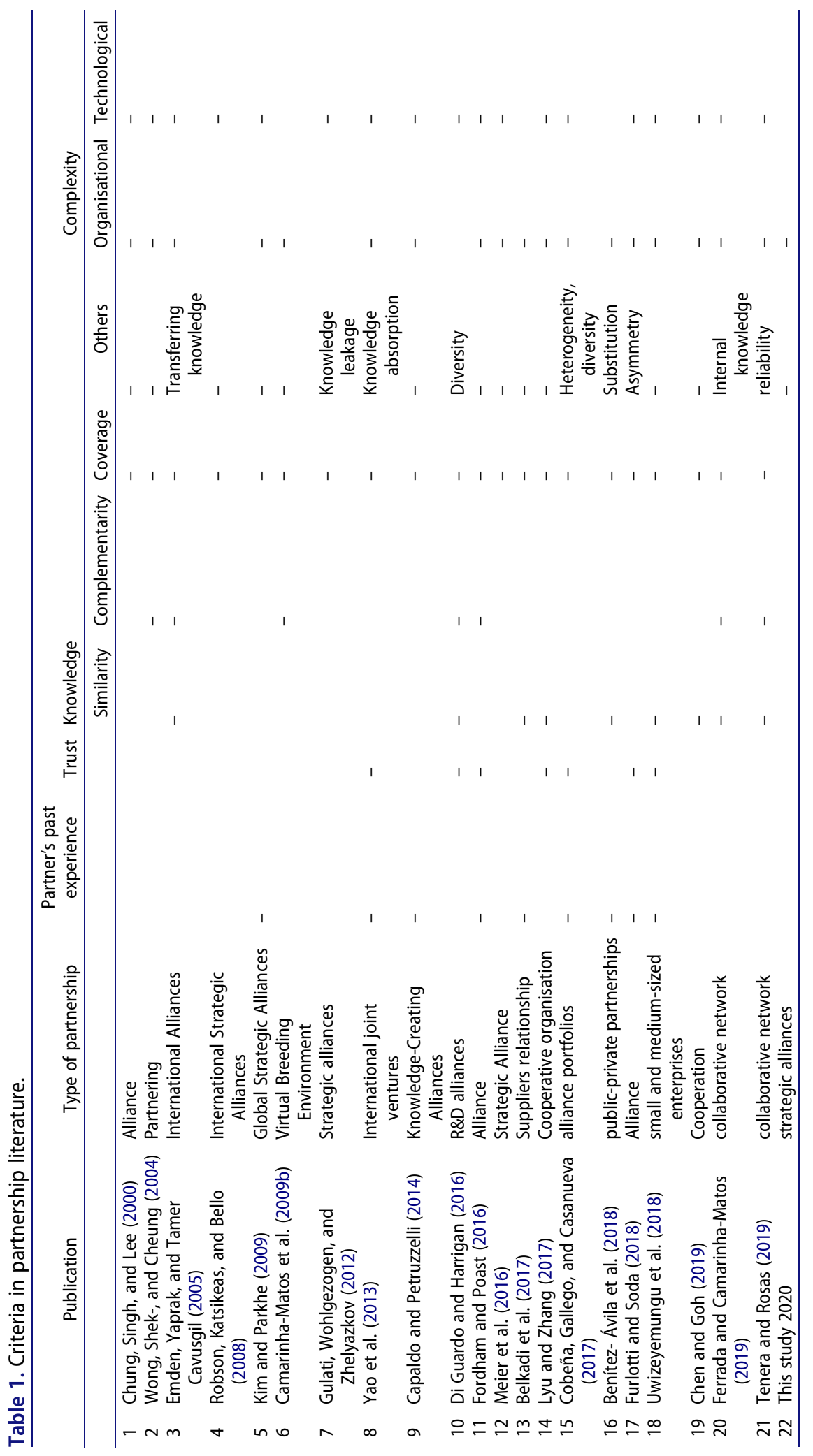




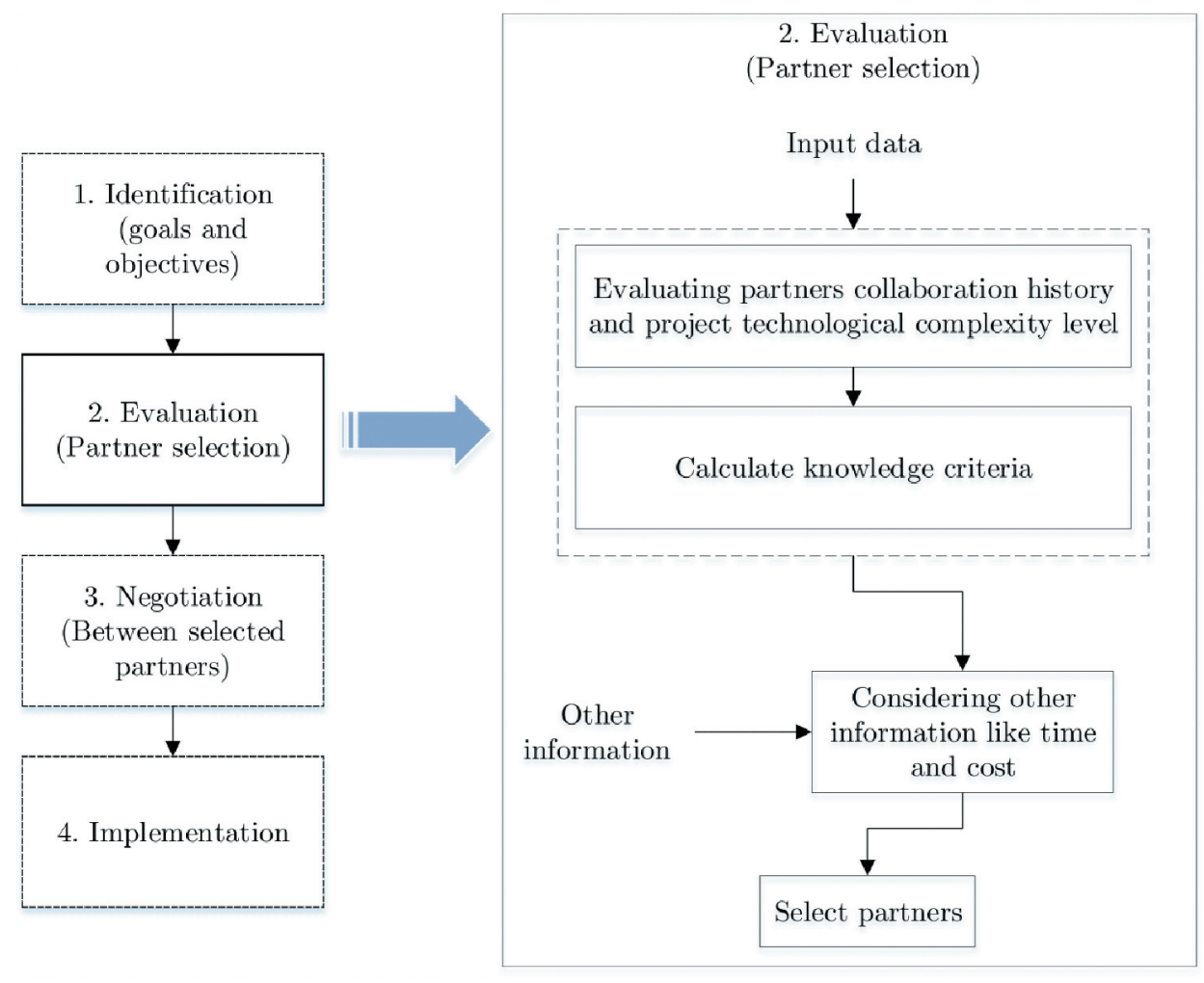

Figure 3. A schematic overview of the proposed framework.

Table 2. Summary of hypotheses.

\begin{tabular}{|c|c|c|c|}
\hline & & \multirow[b]{2}{*}{$\begin{array}{l}\text { Partner has known each } \\
\text { other or past project } \\
\text { succeeded }\end{array}$} & Alliance \\
\hline & & & $\begin{array}{l}\text { First collaboration or past } \\
\text { project with difficulties }\end{array}$ \\
\hline \multirow[t]{4}{*}{$\begin{array}{l}\text { Technological complexity of } \\
\text { the project }\end{array}$} & $\begin{array}{l}\text { Project technologically } \\
\text { simple }\end{array}$ & $\begin{array}{l}\text { Confident with the } \\
\text { optimist estimation for } \\
\text { the project }\end{array}$ & $\begin{array}{l}\text { Confident with the optimist } \\
\text { estimation for the project }\end{array}$ \\
\hline & & $\begin{array}{l}\text { Select partners knowing } \\
\text { that complementarity is } \\
\text { more important }\end{array}$ & $\begin{array}{l}\text { Select partners knowing } \\
\text { that similarity and } \\
\text { complementarity are } \\
\text { more important }\end{array}$ \\
\hline & $\begin{array}{l}\text { High technological } \\
\text { challenges }\end{array}$ & $\begin{array}{l}\text { Considering the } \\
\text { pessimistically } \\
\text { estimation for the } \\
\text { project }\end{array}$ & $\begin{array}{l}\text { Considering the } \\
\text { pessimistically estimation } \\
\text { for the project }\end{array}$ \\
\hline & & $\begin{array}{l}\text { Select partners knowing } \\
\text { that complementarity } \\
\text { and coverage are more } \\
\text { important }\end{array}$ & $\begin{array}{l}\text { Select partners knowing } \\
\text { that similarity, } \\
\text { complementarity and } \\
\text { coverage are important }\end{array}$ \\
\hline
\end{tabular}

The above hypotheses (summarised in Table 2) provide a starting point to design a partner selection decision-making tool to maximise the chance of success in a complex project. 


\section{Proposed framework}

Each project is a context presenting specificities. A new project can be evaluated from the technological point of view to see whether it is simple or difficult. Moreover, a project can be done by partners having had (successful or unsuccessful) collaboration in the past, or it could be their first collaboration. These factors can influence the level of trust between partners. Given a project context, similarity, complementarity and coverage are used as criteria to choose partners (Figure 3). This suggested framework is presented in Table 2. This framework is constructed based on the literature review and proposed hypotheses in (Section 2 and Section 3).

The idea is to consider similarity, complementarity and coverage simultaneously but weighting them based on partners' characteristics. This criteria weighting based on knowledge is depicted in Figure 4. As an example, similarity and coverage are more important than complementarity when we are describing a challenging project with new partners, whereas similarity is a critical criterion for communication between partners without past experiences. In addition, broad 'coverage' creates more flexibility in management when the project is technologically complex because with broader coverage, firms will have a wider spectrum of knowledge (and possibly also a larger quantity) with which to address the problems (and surprises) that arise during the project (Duncan (1995)).

An interpretation for Figure 4 is that if partners are familiar with each other, they can avoid the need for similarity and can work well with more complementary knowledge bases. By contrast, if they are relative strangers, to create the trust they need, more similar

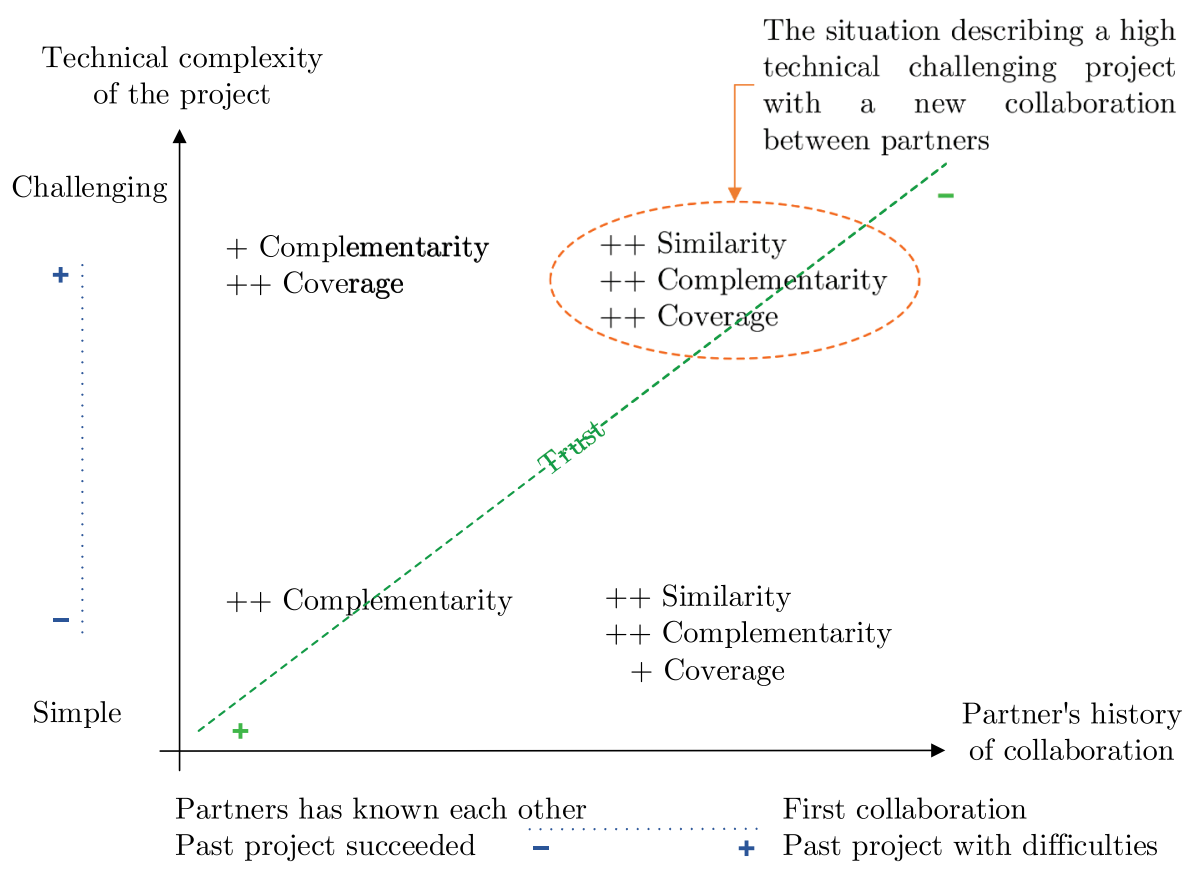

Figure 4. An overview of criteria weighting based on knowledge. 
knowledge bases facilitate easier collaboration which will help build trust. In addition, we should look to the complexity level of the project, since for a simple project the need for complementarity and coverage is reduced. Even if knowledge coverage of the partnership is not complete vis-a-vis the project, if the project is simple, it is likely that the partners can either create the new knowledge they need or find it outside the partnership. Incomplete coverage does not necessarily erode trust. By contrast, if the project is complex, complementarity and coverage play more critical roles in establishing trust and finishing the project.

A mathematical model to calculate partnership score for each set of partners is proposed based on their knowledge criteria, and shown in Equation (2) (Deniaud et al. (2017)). Where $a, \beta$ and $\gamma$ are three coefficients that weight knowledge criteria (3).

$$
\begin{gathered}
\text { Partnership score }=a \times \text { Similarity }+\beta \times \text { Complementarity }+\gamma \times \text { Coverage } \\
\qquad a+\beta+\gamma=1
\end{gathered}
$$

In the partner selection phase of alliance formation, there will be in principle many potential partners, and for each set of partners similarity, complementarity and coverage of knowledge can be assessed. We have argued that in different circumstances the three components should be weighted differently, and this is where the experience of the manager is important. The presented framework can be used by an experienced manager to determine suitable weights $(\alpha, \beta, \gamma)$ for knowledge similarity, complementarity and coverage. Equation 2 provides the abstract structure for generating a partnership score for each of the possible set of partners, and that score should indicate the quality of fit for each potential partnership. Looking for partnerships with high scores is likely to increase mutual trust and also the chance of success in alliances. We have argued that it is important to treat these two axes of evaluation simultaneously, as they cannot be disentangled.

Figure 5 shows an example of using the proposed framework. At the starting point of the framework, we have a panel of potential partners. These potential partners can be selected among many organisations. This selection can be made by a qualitative judgement based on technological competences, social competencies, and prestige evaluation as explained in (Camarinha-Matos and Macedo (2010)). Also, due to the importance of project objectives, it can be considered as an input of the framework. Then, different possible combinations of partnerships can be made to be evaluated. There are two situations to make different combinations, situation 1 is when there is no preference in having a special partner in alliance and all the possible combinations are taken to account, and situation 2 is related to making different combinations when some of the partners are already chosen based on previous contracts or policies. The next step is to evaluate the partner's past experiences and the degree of complexity of the project. Then, all the knowledge criteria for each set of partnerships need to be calculated using Figure 2 and Equation 1. In the next step, the decision-maker can use Table 2 to estimate proper knowledge weight $(\alpha, \beta$ and $\gamma$ ). Afterwards, the partnership score using Equation 2 should be calculated for all the possible combinations of partners. The last step is to check other information and limitation like the cost and time of the partnership with the highest score. Finally, the partnership with the highest partnership score can be selected as the best fit. 


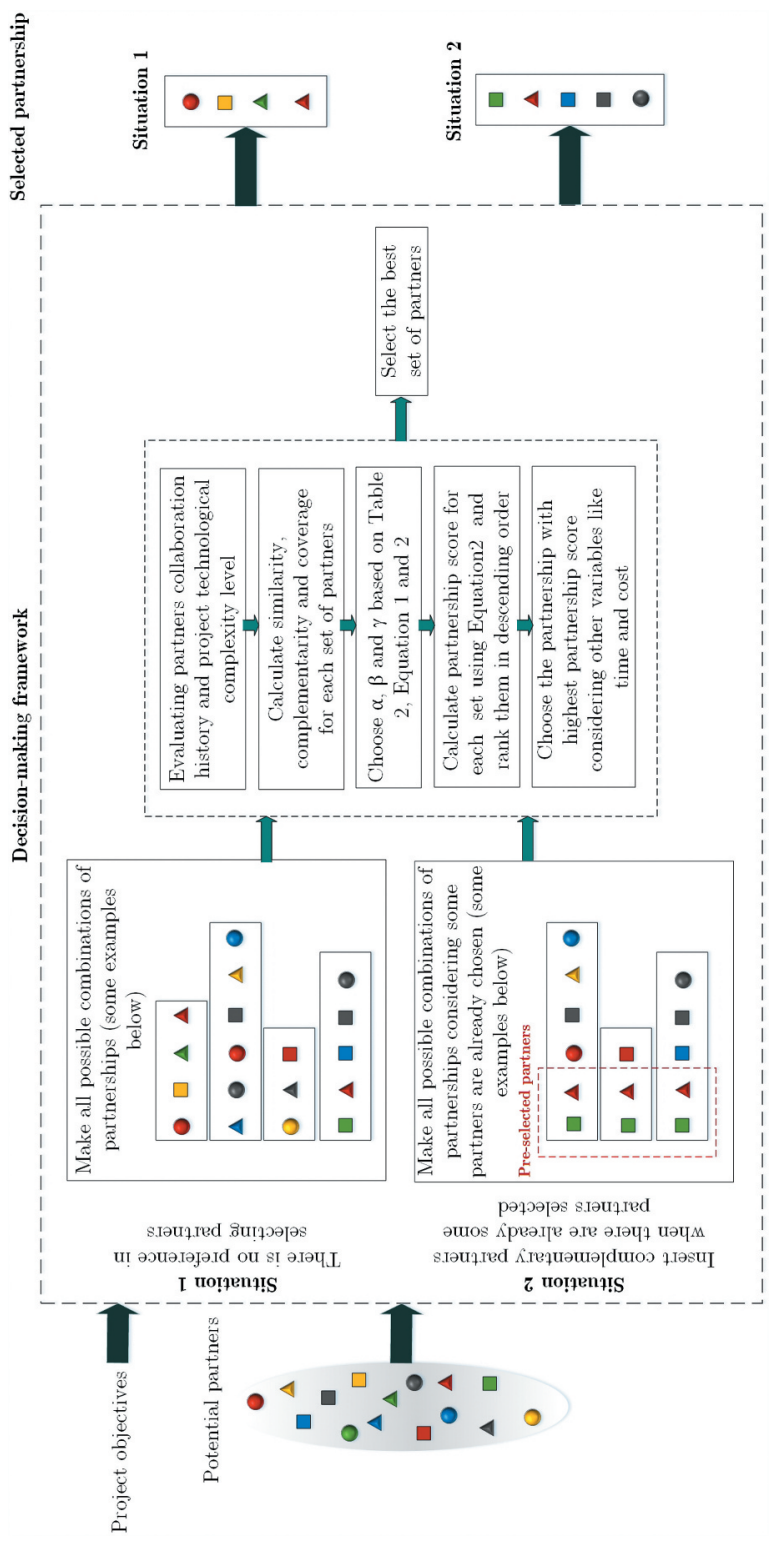

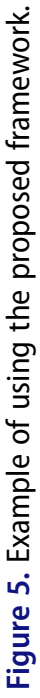




\section{Conclusion and discussion}

In this paper, we have proposed a novel framework for strategic alliance partner selection based on the joint characteristics of projects and partners. This research is relying on a systematic review of previous studies in partner selection of different collaboration communities such as collaborative network, virtual breeding environment and strategic alliance. A lack of trust is the source of many alliance failures, and having reasonable expectations based on an accurate reflection of partners' resources and abilities as they relate to this particular project goes a long way to creating maintainable trust.

\subsection{Conclusion}

Based on generalisations from the literature, this paper has developed a novel framework that permits decision-making to adapt to the needs of the project in order to help decision-makers maximise the chances of project's success. The contribution of this paper is that in this framework two aspects of the project and partnership are considered before selecting partners for alliances. First, it is important to examine past experiences of potential partners to know whether they have (successfully) collaborated in the past. This part of the evaluation helps to determine which criteria will drive the next part of the process of partner selection, which looks at knowledge fit complementarity, similarity or coverage. Second, it is also critical to evaluate the complexity of the project. Project complexity interacts with partners' knowledge stocks and with the partnership's knowledge fit. A successful use of this framework is likely to invest the project with a fundamental necessity, namely trust among the partners.

\subsection{Managerial insight}

The presented framework can be a useful tool for decision-makers in real-world projects, since it provides managers a concrete, evidence-based path with which to evaluate candidate alliance partners, to calculate a partnership score based on defined criteria, to choose the best combination of partners for alliance formation, and to estimate the time and budget of a project more realistically.

Our purpose is that the proposed integrated framework can help in better understanding the relationship between project complexity, past experience of partners and their knowledge, the innovation potential of alliances and their chances of success. This should permit a stronger ability to form pertinent goals and also to decrease the risk of failure in strategic alliances.

\subsection{Limitations and future research}

There are some limitations in this study that need to be considered. Therefore, this research can be seen as a starting point for future studies on the relationships between trust, knowledge criteria, project complexity and partner familiarity, when considering selection of partners in strategic alliances. We have proposed four hypotheses based on 
a close reading of the literature, and they could each be studied empirically to examine their veracity. Equally, they could be implemented through a simulation model to examine their effects on alliance formation and innovation success. The current version of the framework can of course be further elaborated and customised to fit particular circumstances, adding further criteria that may be relevant for alliance partner selection.

\section{Acknowledgement}

This study is a part of the project KAAT (Knowledge Alliance in Air Transport), which is under the support of the Erasmus and European Union. We have to express our appreciation to all industrial partners of the project for their implication in the project.

\section{Disclosure statement}

No potential conflict of interest was reported by the authors.

\section{ORCID}

Maliheh Vaez-Alaei (D) http://orcid.org/0000-0001-6971-0201

loana Deniaud (D) http://orcid.org/0000-0002-8847-5689

François Marmier (iD http://orcid.org/0000-0001-9264-293X

Didier Gourc (iD) http://orcid.org/0000-0003-3500-168X

\section{References}

Afsarmanesh, H., L. M. Camarinha-Matos, and M. Simon Samwel. 2010. "Models, Methodologies, and Tools Supporting Establishment and Management of Second-Generation VBEs." IEEE Transactions on Systems, Man, and Cybernetics, Part C (Applications and Reviews) 41 (5): 692-710. doi:10.1109/ TSMCC.2010.2076326.

Afsarmanesh, H., L. M. Camarinha-Matos, and S. S. Msanjila. 2009. "On Management of 2nd Generation Virtual Organizations Breeding Environments." Annual Reviews in Control 33 (2): 209-219. doi:10.1016/j.arcontrol.2009.05.007.

Ahlf, H., S. Horak, A. Klein, and S.-W. Yoon. 2019. "Demographic Homophily, Communication and Trust in Intra-organizational Business Relationships." Journal of Business \& Industrial Marketing 34 (2): 474-487. doi:10.1108/JBIM-03-2018-0093.

Ahuja, G., and R. Katila. 2001. "Technological Acquisitions and the Innovation Performance of Acquiring Firms: A Longitudinal Study." Strategic Management Journal 22 (3): 197-220. doi:10.1002/smj.157.

Alsaad, A., R. Mohamad, and N. A. Ismail. 2017. "The Moderating Role of Trust in Business to Business Electronic Commerce (B2B EC) Adoption." Computers in Human Behavior 68: 157-169. doi:10.1016/j.chb.2016.11.040.

Aulakh, P. S., M. Kotabe, and A. Sahay. 1996. "Trust and Performance in Cross-Border Marketing Partnerships: A Behavioral Approach." Journal of International Business Studies 27 (5): 1005-1032. doi:10.1057/palgrave.jibs.8490161.

Ávila, B., A. H. Camilo, G. Dewulf, and J. Henseler. 2018. "Inter-Play of Relational and Contractual Governance in Public-private Partnerships: The Mediating Role of Relational Norms, Trust and Partners' Contribution." International Journal of Project Management 36 (3): 429-443. doi:10.1016/ j.ijproman.2017.12.005. 
Baccarini, D. 1996. "The Concept of Project Complexity—a Review." International Journal of Project Management 14 (4): 201-204. doi:10.1016/0263-7863(95)00093-3.

Bakhshi, J., V. Ireland, and A. Gorod. 2016. "Clarifying the Project Complexity Construct: Past, Present and Future." International Journal of Project Management 34 (7): 1199-1213. doi:10.1016/j. ijproman.2016.06.002.

Becker, L. C. 1996. “Trust as Noncognitive Security about Motives.” Ethics 107 (1): 43-61. doi:10.1086/ 233696.

Belkadi, F., M. Messaadia, A. Bernard, and D. Baudry. 2017. "Collaboration Management Framework for OEM-suppliers Relationships: A Trust-based Conceptual Approach." Enterprise Information Systems 11 (7): 1018-1042. doi:10.1080/17517575.2016.1250166.

Ben Salah, S., W. B. Yahia, O. Ayadi, and F. Masmoudi. 2018. "Definition and Classification of Collaborative Network: MCDM Approaches for Partner Selection Problem." In Design and Modeling of Mechanical Systems-III, edited by Mohamed Haddar, Fakher Chaari, Abdelmajid Benamara, Mnaouar Chouchane, Chafik Karra, and Nizar Aifaoui, Cham, 733-744. Springer International Publishing.

Bernus, P., T. Goranson, J. Gøtze, A. Jensen-Waud, H. Kandjani, A. Molina, O. Noran, et al. 2016. "Enterprise Engineering and Management at the Cross- Roads". Computers in Industry 79: 87-102. doi: 10.1016/j.compind.2015.07.010.

Braunerhjelm, P. 2010. "Entrepreneurship, Innovation and Economic Growth - past Experience, Current Knowledge and Policy Implications." Working Paper Series in Economics and Institutions of Innovation 224. Royal Institute of Technology, CESIS - Centre of Excellence for Science and Innovation Studies.

Bruner, R., and R. Spekman. 1998. "The Dark Side of Alliances: Lessons from Volvo- Renault." European Management Journal 16 (2): 136-150. doi:10.1016/S0263-2373(97)00083-2.

Camarinha-Matos, L. M., A. I. Oliveira, M. Sesana, N. Galeano, D. Demsar, F. Baldo, and T. Jarimo. 2009b. "A Framework for Computer-assisted Creation of Dynamic Virtual Organisations." International Journal of Production Research 47 (17): 4661-4690. doi:10.1080/00207540902847272.

Camarinha-Matos, L. M., and H. Afsarmanesh. 2005. "Collaborative Networks: A New Scientific Discipline." Journal of Intelligent Manufacturing 16 (4-5): 439-452. doi:10.1007/s10845-0051656-3.

Camarinha-Matos, L. M., and H. Afsarmanesh. 2012. "Taxonomy of Collaborative Networks Forms: FInES Task Force on Collaborative Networks and SOCOLNET-Society of Collaborative Networks."

Camarinha-Matos, L. M., and H. Afsarmanesh. 2018. "Roots of Collaboration: Nature- Inspired Solutions for Collaborative Networks." IEEE Access 6: 30829-30843. doi:10.1109/ACCESS.2018.2845119.

Camarinha-Matos, L. M., H. Afsarmanesh, N. Galeano, and A. Molina. 2009a. "Collaborative Networked organizations-Concepts and Practice in Manufacturing Enterprises." Computers \& Industrial Engineering 57 (1): 46-60. doi:10.1016/j.cie.2008.11.024.

Camarinha-Matos, L. M., and P. Macedo. 2010. "A Conceptual Model of Value Systems in Collaborative Networks." Journal of Intelligent Manufacturing 21 (3): 287-299. doi:10.1007/ s10845-008-0180-7.

Camarinha-Matos, L. M., R. Fornasiero, J. Ramezani, and F. Ferrada. 2019. "Collaborative Networks: A Pillar of Digital Transformation." Applied Sciences 9 (24): 5431. doi:10.3390/app9245431.

Camarinha-Matos, L. M., and X. Boucher. 2012. "Sustainable Collaborative Networks - Case Studies." Production Planning \& Control 23 (4): 237-239. doi:10.1080/09537287.2011.627653.

Camarinha-Matos, Luis M., H. Afsarmanesh, and X. Boucher. 2010. "The Role of Collaborative Networks in Sustainability." In Collaborative Networks for a Sustainable World, edited by Luis M. Camarinha-Matos, Xavier Boucher, and Hamideh Afsarmanesh, Berlin, Heidelberg, 1-16. Springer Berlin Heidelberg.

Capaldo, A., and A. M. Petruzzelli. 2014. "Partner Geographic and Organizational Proximity and the Innovative Performance of Knowledge-creating Alliances." European Management Review 11 (1): 63-84. doi:10.1111/emre.12024.

Chen, W., and M. Goh. 2019. "Mechanism for Cooperative Partner Selection: Dual-factor Theory Perspective." Computers \& Industrial Engineering 128: 254-263. doi:10.1016/j.cie.2018.12.040. 
Chen, Y.-H., T.-P. Lin, and D. C. Yen. 2014. "How to Facilitate Inter-organizational Knowledge Sharing: The Impact of Trust." Information \& Management 51 (5): 568-578. doi:10.1016/j. im.2014.03.007.

Chung, S., H. Singh, and K. Lee. 2000. "Complementarity, Status Similarity and Social Capital as Drivers of Alliance Formation." Strategic Management Journal 21 (1): 1-22. doi:10.1002/(SICI)10970266(200001)21:1<1::AID-SMJ63>3.0.CO;2-P.

Cobeña, M., Á. Gallego, and C. Casanueva. 2017. "Heterogeneity, Diversity and Complementarity in Alliance Portfolios." European Management Journal 35 (4): 464-476. doi:10.1016/j.emj.2016.12.005.

Cook, K. S., R. Hardin, and M. Levi. 2005. "Cooperation without Trust?" Russell Sage Foundation. http://www.jstor.org/stable/10.7758/9781610441353

Crispim, J., N. Rego, and J. P. de Sousa. 2015. "Stochastic Partner Selection for Virtual Enterprises: A Chance-constrained Approach." International Journal of Production Research 53 (12): 3661-3677. doi:10.1080/00207543.2014.986301.

Deitz, G. D., M. Tokman, R. Glenn Richey, and R. M. Morgan. 2010. "Joint Venture Stability and Cooperation: Direct, Indirect and Contingent Effects of Resource Complementarity and Trust." Industrial Marketing Management 39 (5): 862-873. doi:10.1016/j.indmarman.2010.01.003.

Deniaud, I. F., F. Marmier, D. Gourc, and X. Labaume. 2017. "How risks and innovativeness influence the selection of partner in NPD alliances." In 2017 IEEE 19th Conference on Business Informatics (CBI), Vol. 1, Thessaloniki, Greece, Jul., 62-69. Institute of Electrical and Electronics Engineers Inc. Conference of 19th IEEE Conference on Business Informatics, CBI 2017, https://hal.archivesouvertes.fr/hal-01666266

Di Guardo, M. A. R. I. A. C. H. I. A. R. A., and K. R. Harrigan. 2016. "Shaping the Path to Inventive Activity: The Role of past Experience in R\&D Alliances." The Journal of Technology Transfer 41 (2): 250-269. doi:10.1007/s10961-015-9409-8.

Doloi, H. 2009. "Relational Partnerships: The Importance of Communication, Trust and Confidence and Joint Risk Management in Achieving Project Success." Construction Management and Economics 27 (11): 1099-1109. doi:10.1080/01446190903286564.

Dorogovtsev, S. N., and J. F. F. Mendes. 2013. Evolution of Networks: From Biological Nets to the Internet and WWW. Oxford: Oxford University Press.

Duncan, N. B. 1995. "Capturing Flexibility of Information Technology Infrastructure: A Study of Resource Characteristics and Their Measure." Journal of Management Information Systems 12 (2): 37-57. doi:10.1080/07421222.1995.11518080.

Durugbo, C. 2016. "Collaborative Networks: A Systematic Review and Multi-level Framework." International Journal of Production Research 54 (12): 3749-3776. doi:10.1080/00207543.2015.1122249.

Elhabib, N., X. Boucher, and S. Peillon. 2010. "Engineering of Service Oriented Collaborative Network." 11th IFIP WG 5.5 Working Conference on Virtual Enterprises (PRO-VE), Oct 2010, SaintEtienne, France., pp. 461-468. doi:10.1007/978-3-642-15961-9_55.

Emden, Z., A. Yaprak, and S. Tamer Cavusgil. 2005. "Learning from Experience in International Alliances: Antecedents and Firm Performance Implications." Journal of Business Research 58 (7): 883-892. doi:10.1016/j.jbusres.2003.10.008.

Ferrada, F., and L. M. Camarinha-Matos. 2019. "A Modelling Framework for Collaborative Network Emotions." Enterprise Information Systems 13 (7-8): 1164-1194. doi:10.1080/17517575.2019.1633583.

Fordham, B., and P. Poast. 2016. "All Alliances are Multilateral: Rethinking Alliance Formation." Journal of Conflict Resolution 60 (5): 840-865. doi:10.1177/0022002714553108.

Furlotti, M., and G. Soda. 2018. "Fit for the Task: Complementarity, Asymmetry, and Partner Selection in Alliances." Organization Science 29 (5): 837-854. doi:10.1287/orsc.2018.1205.

Gou J., Q. Liu, W. Mu, W. Ying, H. Afsarmanesh, and F. Benaben F. 2019. A Digital-Enabled Framework for Intelligent Collaboration in Small Teams. In Collaborative Networks and Digital Transformation. PRO-VE 2019. IFIP Advances in Information and Communication Technology, edited by CamarinhaMatos L., Afsarmanesh H., Antonelli D., vol 568. Springer, Cham. doi:10.1007/978-3-030-28464$0 \_18$

Gulati, R., F. Wohlgezogen, and P. Zhelyazkov. 2012. "The Two Facets of Collaboration: Cooperation and Coordination in Strategic Alliances." The Academy of Management Annals 6 (1): 531-583. doi:10.5465/19416520.2012.691646. 
Haghbin, S., and P. Davoudi. 2014. "Investigation of Similarities between Collaborative Network and General Contractors-Literature Review." Procedia Technology 16: 979-987. doi:10.1016/j. protcy.2014.10.051.

Hameed, M. A., and S. Counsell. 2014. "Establishing Relationships between Innovation Characteristics and IT Innovation Adoption in Organisations: A Meta-analysis Approach." International Journal of Innovation Management 18 (1): 1450007. doi:10.1142/S1363919614500078.

Harbison, J. R. 1998. "Smart Alliances: A Practical Guide to Repeatable Success." In The Jossey-Bass Business \& Management Series, 1st ed. San Francisco, California: Jossey-Bass.

Harbison, J. R., and P. Pekar. 1997. Cross-Border Alliances in the Age of Collaboration. New York, BoozAllen \& Hamilton.

Ho, W., X. Xiaowei, and P. K. Dey. 2010. "Multi-criteria Decision Making Approaches for Supplier Evaluation and Selection: A Literature Review." European Journal of Operational Research 202 (1): 16-24. doi:10.1016/j.ejor.2009.05.009.

Huang, M.-C., H.-H. Hsiung, and L. Ting-Chun. 2015. “Reexamining the Relationship between Control Mechanisms and International Joint Venture Performance: The Mediating Roles of Perceived Value Gap and Information Asymmetry." Asia Pacific Management Review 20 (1): 32-43. doi:10.1016/j.apmrv.2014.12.004.

Inkpen, A. 1998. "Learning, Knowledge Acquisition, and Strategic Alliances." European Management Journal 16 (2): 223-229. doi:10.1016/S0263-2373(97)00090-X.

Kadefors, A. 2004. "Trust in Project Relationships-inside the Black Box." International Journal of Project Management 22 (3): 175-182. doi:10.1016/S0263-7863(03)00031-0.

Kamel, M., A. Benzekri, F. Barrère and R. Laborde, "Evaluating the Virtual Organizations security solutions using the ISO/IEC 17799 standard," 2007 IEEE International Technology Management Conference (ICE), Sophia Antipolis, France, 2007, pp. 1-8.

Kim, J., and A. Parkhe. 2009. "Competing and Cooperating Similarity in Global Strategic Alliances: An Exploratory Examination." British Journal of Management 20 (3): 363-376. doi:10.1111/j.14678551.2008.00580.x.

Kohl, H., R. Orth, O. Riebartsch, M. Galeitzke, and J.-P. Cap. 2015. "Support of Innovation Networks in Manufacturing Industries through Identification of Sustainable Collaboration Potential and Best-practice Transfer." Procedia CIRP 26: 185-189. doi:10.1016/j.procir.2014.07.055.

Kramer, R. M., and T. R. Tyler. 1995. Trust in Organizations: Frontiers of Theory and Research. Thousand Oaks, California: Sage Publications.

Lai, B., and D. Reiter. 2000. "Democracy, Political Similarity, and International Alliances, 1816-1992." Journal of Conflict Resolution 44 (2): 203-227. doi:10.1177/0022002700044002003.

Li, H., Q. Zhang, and Z. Zheng. 2019. "A Mediating Effect of Knowledge Integration and Moderating Effect of Organizational Task Environment." Enterprise Information Systems 13 (9): 1323-1346. doi:10.1080/17517575.2019.1638973.

Loichate, M. 2012. "State of the Art of Collaborative Networks for Service-based Innovation Ecosystems." In Service based Innovation Ecosystems of the MSEE project - Manufacturing SErvices Ecosystem

Lyu, H., and Z. Zhang. 2017. "Incentives for Knowledge Sharing: Impact of Organisational Culture and Information Technology." Enterprise Information Systems 11 (9): 1416-1435.

Maleki, M., E. Shevtshenko, and V. Cruz-Machado. 2013. "Comparative Analysis of Customer Value Dimensions." Engineering Economics 24 (5): 488-495.

Mat, N., A. Che, Y. Cheung, and H. Scheepers. 2009. "Partner Selection: Criteria for Successful Collaborative Network." In 20th Australian conference on information systems, Monash University, Melbourne, Australia, Vol. 2.

Meier, M., M. Lütkewitte, T. Mellewigt, and C. Decker. 2016. "How Managers Can Build Trust in Strategic Alliances: A Meta-analysis on the Central Trust-building Mechanisms." Journal of Business Economics 86 (3): 229-257. doi:10.1007/s11573-015-0777-1.

MintzbergH. 1989. The Structuring of Organizations. In Readings in Strategic Management, edited by Asch D., Bowman C. Palgrave, London. https://doi.org/10.1007/978-1-349-20317-8_23

Moorman, C., R. Deshpande, and G. Zaltman. 1993. "Factors Affecting Trust in Market Research Relationships." Journal of Marketing 57 (1): 81-101. doi:10.1177/002224299305700106. 
Mowery, D. C., J. E. Oxley, and B. S. Silverman. 1996. "Strategic Alliances and Interfirm Knowledge Transfer." Strategic Management Journal 17 (S2): 77-91. doi:10.1002/smj.4250171108.

Mowery, D. C., J. E. Oxley, and B. S. Silverman. 1998. "Technological Overlap and Interfirm Cooperation: Implications for the Resource-based View of the Firm." Research Policy 27 (5): 507-523. doi:10.1016/S0048-7333(98)00066-3.

Msanjila, S. S., and H. Afsarmanesh. 2008. "Trust Analysis and Assessment in Virtual Organization Breeding Environments." International Journal of Production Research 46 (5): 1253-1295. doi:10.1080/00207540701224350.

Msanjila, S. S., and H. Afsarmanesh. 2011. "On Modelling Evolution of Trust in Organisations Towards Mediating Collaboration." Production Planning \& Control 22 (5-6): 518-537. doi:10.1080/ 09537287.2010.536623.

Msanjila S.S., and H. Afsarrnanesh. 2006. Assessment and Creation of Trust in VBEs. In NetworkCentric Collaboration and Supporting Frameworks. PRO-VE 2006. IFIP International Federation for Information Processing, vol 224. Springer, Boston, MA. https://doi.org/10.1007/978-0-387-382692_17

Mudambi, S. M., and S. Tallman. 2010. "Make, Buy or Ally? Theoretical Perspectives on Knowledge Process Outsourcing through Alliances." Journal of Management Studies 47 (8): 1434-1456. doi:10.1111/j.1467-6486.2010.00944.x.

Muthusamy, S. K., and M. A. White. 2005. "Learning and Knowledge Transfer in Strategic Alliances: A Social Exchange View." Organization Studies 26 (3): 415-441. doi:10.1177/0170840605050874.

Nguyen, L. D., L. Le-Hoai, D. Q. Tran, C. N. Dang, and C. V. Nguyen. 2019. "Effect of Project Complexity on Cost and Schedule Performance in Transportation Projects." Construction Management and Economics 37 (7): 384-399. doi:10.1080/01446193.2018.1532592.

Oliveiral A.I., L. M. Camarinha-Matos, and M. Pouly. 2008. Agreement Negotiation Support in VO Creation. In Pervasive Collaborative Networks. PRO-VE 2008. IFIP - The International Federation for Information Processing, edited by Camarinha-Matos L.M., Picard W., vol 283. Boston, MA: Springer. doi:10.1007/978-0-387-84837-2_11

Osborn, R. N., and J. Hagedoorn. 1997. "The Institutionalization and Evolutionary Dynamics of Interorganizational Alliances and Networks." Academy of Management Journal 40 (2): 261-278.

Osório A.L., Camarinha-Matos L.M., Afsarmanesh H., Belloum A. 2019. Towards a Mobility Payment Service Based on Collaborative Open Systems. In Collaborative Networks and Digital Transformation. PRO-VE 2019. IFIP Advances in Information and Communication Technology, edited by Camarinha-Matos L., Afsarmanesh H., Antonelli D, vol 568. Springer, Cham. https://doi.org/10. 1007/978-3-030-28464-0_33

Park, J.-G., and J. Lee. 2014. "Knowledge Sharing in Information Systems Development Projects: Explicating the Role of Dependence and Trust." International Journal of Project Management 32 (1): 153-165. doi:10.1016/j.ijproman.2013.02.004.

Polyantchikov, I., E. Shevtshenko, T. Karaulova, T. Kangilaski, and L. M. Camarinha-Matos. 2017. "Virtual Enterprise Formation in the Context of a Sustainable Partner Network." Industrial Management \& Data Systems 117 (7): 1446-1468. doi:10.1108/IMDS-07-2016-0274.

Relich, M., and P. Pawlewski. 2018. "A Case-based Reasoning Approach to Cost Estimation of New Product Development." Neurocomputing 272: 40-45. doi:10.1016/j.neucom.2017.05.092.

Robson, M. J., C. S. Katsikeas, and D. C. Bello. 2008. "Drivers and Performance Outcomes of Trust in International Strategic Alliances: The Role of Organizational Complexity." Organization Science 19 (4): 647-665. doi:10.1287/orsc.1070.0329.

Romero, D., and A. Molina. 2011. "Green Virtual Enterprise Breeding Environment Reference Framework." In Adaptation and Value Creating Collaborative Networks, edited by Luis M. Camarinha-Matos, Alexandra Pereira-Klen, and Hamideh Afsarmanesh, 545-555. Springer Berlin Heidelberg.

Rosas, J., P. Urze, A. Tenera, A. Abreu, and Luis M. Camarinha-Matos. 2017. “Exploratory Study on Risk Management in Open Innovation." In 18th Working Conference on Virtual Enterprises (PROVE), edited by Luis M. Camarinha-Matos, Hamideh Afsarmanesh, and Rosanna Fornasiero, Vol. AICT- 
506 of Collaboration in a Data-Rich World, Vicenza, Italy, Sep., 527-540. Springer International Publishing. Part 14: Risk and Trust Analysis in CNs. https://hal.inria.fr/hal-01674888.

Rosenkopf, L., and P. Almeida. 2003. "Overcoming Local Search through Alliances and Mobility." Management Science 49 (6): 751-766. doi:10.1287/mnsc.49.6.751.16026.

Sampson, R. C. 2002. "Experience, Learning \& Collaborative Returns in R\&D Alliances." SSRN Scholarly Paper ID 309944. Rochester, NY: Social Science Research Network.

Sarker, S. A. O. N. E. E., D. B. Nicholson, K. D. Joshi, and K. D. Joshi. 2005. "Knowledge Transfer in Virtual Systems Development Teams: An Exploratory Study of Four Key Enablers." IEEE Transactions on Professional Communication 48 (2): 201-218. doi:10.1109/TPC.2005.849650.

Shevtshenko, E., I. Poljantchikov, K. Mahmooda, T. Kangilasski, and A. Norta. 2015. "Collaborative Project Management Framework for Partner Network Initiation." Procedia Engineering 100: 159-168. doi:10.1016/j.proeng.2015.01.354.

Stuart, T. E. 1998. "Network Positions and Propensities to Collaborate: An Investigation of Strategic Alliance Formation in a High-technology Industry." Administrative Science Quarterly 43 (3): 668-698. doi:10.2307/2393679.

Sunardi, O., J. H. Tjakraatmadja, and Y. R. Bangun. 2015. "Human Capital Traits and Informal Knowledge Sharing: The Role of Reciprocity Norm, Mutual Trust, and Cultural Interpretation Perspective." International Journal of Knowledge Management Studies 6 (2): 123-135. doi:10.1504/IJKMS.2015.071759.

Tenera, A., and J. Rosas. 2019. "Collaborative Networks Management from a Theory of Constraints Perspective." In 20th Working Conference on Virtual Enterprises (PROVE), edited by Luis M. Camarinha-Matos, Hamideh Afsarmanesh, and Dario Antonelli, Vol. AICT-568 of Collaborative Networks and Digital Transformation, Turin, Italy, Sep., 271-282. Springer International Publishing. Part 7: Collaborative Business Ecosystems and Processes, https://hal.inria.fr/hal02478800

Todeva, E., and D. Knoke. 2005. "Strategic Alliances and Models of Collaboration." Management Decision 43 (1): 123-148. doi:10.1108/00251740510572533.

Uwizeyemungu, S., L. Raymond, P. Poba-Nzaou, and S.-P. Josée. 2018. "The Complementarity of IT and HRM Capabilities for Competitive Performance: A Configurational Analysis of Manufacturing and Industrial Service SMEs." Enterprise Information Systems 12 (10): 1336-1358. doi:10.1080/ 17517575.2018 .1448118$.

Vaez-Alaei, M., I. Deniaud, F. Marmier, D. Gourc, and R. Cowan. 2019. "A Decision-making Framework Based on Knowledge Criteria for Network Partner Selection." In 2019 International Conference on Industrial Engineering and Systems Management (IESM), Shanghai, China, pp. 1-6. doi:10.1109/ IESM45758.2019.8948210.

Vidal, L.-A., and F. Marle. 2008. "Understanding Project Complexity: Implications on Project Management." Kybernetes 37 (8): 1094-1110. doi:10.1108/03684920810884928.

Wong, P., K. Leung-, and P. Ellis. 2002. "Social Ties and Partner Identification in Sino-Hong Kong International Joint Ventures." Journal of International Business Studies 33 (2): 267-289. doi:10.1057/palgrave.jibs.8491016.

Wong, P., P. Shek-, and S.-O. Cheung. 2004. "Trust in Construction Partnering: Views from Parties of the Partnering Dance." International Journal of Project Management 22 (6): 437-446. doi:10.1016/j. ijproman.2004.01.001.

Wu, J.-J., C. Ying-Hueih, and C. Yu-Shuo. 2010. "Trust Factors Influencing Virtual Community Members: A Study of Transaction Communities." Journal of Business Research 63 (9-10): 1025-1032. doi:10.1016/j.jbusres.2009.03.022.

$\mathrm{Xu}$, Q., and M. Qingguo. 2008. "Determinants of ERP Implementation Knowledge Transfer." Information \& Management 45 (8): 528-539. doi:10.1016/j.im.2008.08.004.

Yao, Z., Z. Yang, G. J. Fisher, M. Chaoqun, and E. E. Fang. 2013. “Knowledge Complementarity, Knowledge Absorption Effectiveness, and New Product Performance: The Exploration of International Joint Ventures in China." International Business Review 22 (1): 216-227. doi:10.1016/j.ibusrev.2012.04.002. 